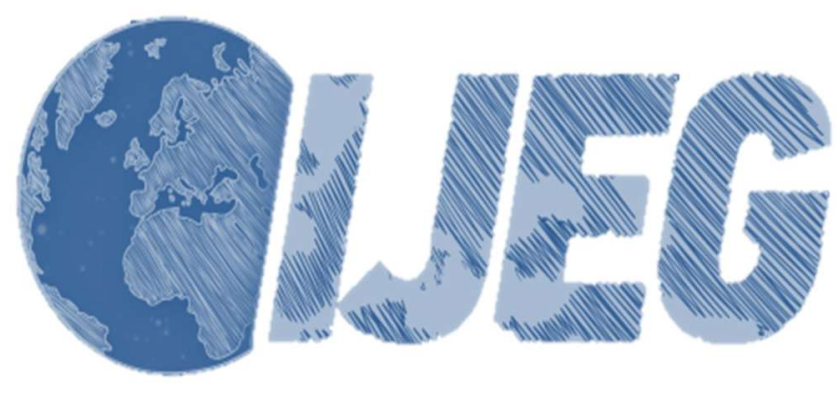

International Journal of Engineering and Geosciences (IJEG), Vol; 3; , Issue; 3, pp. 119-125, October, 2018, ISSN 2548-0960, Turkey, DOI: $10.26833 /$ ijeg. 413833

\title{
DETECTION OF PARAGLIDING FIELDS BY GIS
}

\author{
Kuşçu Şimşek, Ç. ${ }^{1}$, Türk, T. ${ }^{1 *}$, Ödül, H. ${ }^{1}$, and Çelik, M.N. ${ }^{1}$ \\ ${ }^{1}$ Cumhuriyet University, Engineering Faculty, Department of Geomatic Engineering, Sivas, Turkey \\ (cagdas.kuscu/tarikturk/halimeodul2/muzeyencelik@gmail.com);
} ORCID ID 0000-0002-3161-6508; ORCID ID 0000-0002-2671-7590; ORCID ID 0000-0003-0879-7395;
ORCID ID 0000-0002-7107-757X

*Corresponding Author, Received: 09/04/2018, Accepted: 04/05/2018

\begin{abstract}
Nowadays, people living in the city tend to get away from the city and integrate with nature as they find the opportunity to keep away from stress in terms of current living conditions and their effects. This situation is increasing the interest in nature tourism and orientation to nature sports with each passing day. One of nature sports is also paragliding.

In this study, alternative flying fields suitable for paragliding which is one of nature sports within the boundaries of Sivas province, Turkey were automatically determined by Geographical Information Systems (GIS) analyses and the developed user interface program by taking into account the international technical conditions required for flying. The suitability of these fields determined was checked with the flight tests performed in company with the experienced paragliding pilot, and they were proposed as nature tourism areas. With this study carried out, it was ensured that the paragliding fields, which are mainly determined by observational and experimental methods, were scientifically determined in accordance with the international technical specification criteria. Furthermore, a new method has been developed to be able to automatically determine alternative paragliding fields in any city with the help of the introduced GIS-based system and user interface program.
\end{abstract}

Keywords: GIS; Ecotourism; Paragliding; Spatial analysis; Nature-based tourism 


\section{INTRODUCTION}

Nowadays, urban people who are trying to maintain their life in limited recreation and sports areas in cities in the face of increasing urbanization are taking up going to nature by getting away from these artificial spaces (Koçak, 2010; Kienast et al., 2012). People want to integrate with nature to keep away from stress and to be healthy (Kaplan and Ardahan, 2012; Ardahan and Yerlisu Lapa, 2011). Along with this orientation, a quick/easy accessibility expectation brings appropriate areas near the city to the forefront as a need brought about by the fast and intense urban life. However, in the face of this demand, a very limited number of functional rural recreation areas with natural quality in city surroundings and the gradual decrease in existing areas make it compulsory for people to go to recreational tourism areas in further remote areas for recreational purposes to the extent of their economic opportunities and time (Ardahan and Yerlisu Lapa, 2011). This situation, which requires time together with the financial burden, decreases the practicability of nature sports by everyone and causes them to appeal to a certain population (Ekinci et al., 2012).

Natural environment offers recreational opportunities that can be associated with tourism development. Tourism revives in rural areas where nature sports such as trekking, mountain climbing, rafting, paragliding, birdwatching, scuba diving, spelaeology, etc. are done and provides significant economic inputs to the region (Özer and Çavuşoğlu, 2014). According to the definition made by the International Ecotourism Society, ecotourism is the travel made to natural areas in the responsibility of protecting the environment and improving the welfare of local people. Ecotourism includes very different forms such as passive (drawing pictures accompanied by landscape), active (paragliding, mountain bike, etc.), consumption (hunting, fishing) and out-of-consumption (walking, birdwatching, etc.) (Bell et al., 2007). The main purpose of this alternative tourism type, which is different from traditional tourism, is to increase the economic welfare of local people by preserving the natural and cultural resources of the region in a sustainable way (Kiper, 2011). On the other hand, these kinds of sports activities and the increased demand for ecotourism also increase the pressure on nature, which has a delicate balance within itself (Sezgin and Gümüş, 2016). In this respect, the adoption of a sustainability approach in natural areas and the protection of the natural environment require comprehensive planning and the proper management of the resources in the area planned (Koçak, 2010; Bunruamkaew and Murayama, 2011). The symbiotic relationship between human and nature necessitates a rational planning approach (Fung and Wong, 2007).

The ability of GIS to associate information with geographical location provides significant contributions to the development and management of tourism (Hailing et al., 2011). The fact that the economic, social and environmental demands of sustainable development are evaluated together makes the decision-making process difficult in tourism planning (Bahaire and Elliott-White, 1999). Butler (1993) mentions the need for the effective use of GIS to ensure the sustainability of a natural area in the presence of tourism while determining new tourism areas (Hai-ling et al., 2011). In this respect, GIS makes a great contribution to the development of sustainable tourism. GIS plays a role in the supervision of environmental conditions, the examination of the suitability of places, the evaluation of conflicting interests and the modeling of relationships (Bahaire and Elliott-White, 1999). A strong database infrastructure is needed to create the map of the potential resources that can be used in a large area or the scenarios for the use of resources (Kliskey et al., 1999). The current provider of this infrastructure is GIS. The development of GISbased inventories brings objectivity, flexibility, and efficiency to the management of recreational resources (Chhetri and Arrowsmith, 2008).

In particular, there are many studies on the use of GIS in the management of recreational resources. Issues such as tourism transport capacity, sustainable tourism infrastructure planning (Boers and Cottrell, 2007), sustainable land-use planning (Bunruamkaew and Murayama, 2012), determination of areas with potential for ecotourism (Bishop and Hulse, 1994; Boyd et al., 1995; Miler et al., 1998; Tseng et al., 2013; Parladır, 2013), nature-based tourism modeling, recreational use potential modeling (Kliskey, 2000) come to the forefront in these studies. This problem is also related to geographical site selection. In the literature, different studies were performed related to site selection by GIS (Şentürk and Erener, 2017; Rutherford et al., 2015).

Paragliding which is one of the alternative nature sports appealing to adrenaline junkies carries a risk by the way it is done. It is necessary for athletes to receive a license to fly on their own. Apart from the pilot experience, the flying field should meet the technical requirements to ensure safe flying. First of all, appropriate hills are required for paragliding. The land structure of the front of the hill and the climatic conditions should be investigated very well, and their analyses in terms of suitability and risks should be performed by experienced pilots. Appropriate weather conditions (fog, wind, snow, rain, etc.) are important in areas considered for paragliding. The predominant wind direction, slope, and altitude of the take-off field are the most important features that should be primarily evaluated for the safety of the take-off field. Another feature that is essential for the safety of the take-off field is that there should be no barriers in areas within a distance that can endanger the take-off, flight and landing safety on the hills to paraglide. Landing areas should be a flat area away from anything that can cause turbulence (Topay, 2003). It is certain that these scientific determinations will provide convenience in far better elevations during flying and going away for kilometers. Although the determination of flying hills and landing areas with appropriate conditions in large geographies is difficult, the examination of all fields by pilots is also impossible. At this stage, GIS-based studies are crucial for determining potential flying fields.

When the studies carried out on paragliding and seeking a correct answer to the questions of when and where for safe flying are examined, appropriate field selection analyses and the examination of wind potential come to the forefront. One of the major constraints of paragliding sport is meteorological conditions. Weather conditions should be taken into consideration for the 
completion of the activity in a pleasant, safe and comfortable way (Falavarjini, 2015). In the study carried out by Krüger-Franke et al. (1991) on paragliding accidents, they determined that accidents mainly occur due to heavy landing taking place depending on the sudden fluctuations in the wind and thermal pattern and hitting rocky, woody and similar areas. Furthermore, the land structure of the take-off field can also cause accidents (Fasching et al., 1997). In their study, Ceyhan et al. (2014) investigated the suitability of the wind potential of the selected regions for paragliding. It is mentioned that the wind speed and direction along with the geographical characteristics of take-off and landing fields should be taken into account for flight safety in paragliding and that continuity in wind is required so that paragliding can be done. For the reduction of paragliding accidents, the importance given to pilot training needs to be increased and also aerodynamics, suitable thermal and weather conditions should be taught well (Fasching et al., 1997; Schulze et al., 2002).

To perform an appropriate location analysis by including the specific criteria of nature sports types into the scope of evaluation requires multiple data management. In this context, GIS techniques play an important role in managing complex relationships such as the storage, processing, and analysis of a wide variety of spatial data (Chen, 2007; Fung and Wong, 2007; Carreta et al., 2016; Zhang, 2012). The rapid development of technology and the facilitation of information flow have also expanded the areas of usage of GIS. GIS applications are also needed to obtain more useful and productive results in ecotourism studies that require multiple data analysis. However, the fact that it is impossible for anyone, who does not know GIS, to perform all these analyses restricts the usability of GIS. Furthermore, the analysis of so many parameters in a manner associated with each other also brings along the management difficulty of a rather complex and long process. Therefore, a problem that may occur in any of the steps of the procedure in the process of associating all data with each other can affect the whole process and cause time loss by requiring everything to be done from the very beginning. At this point, ensuring that anyone who does not know GIS can use these analyses and facilitating the traceability of this complex process require the development of the user interface program.

In the literature, there are not many studies on the determination of paragliding fields. A study was carried out by Pirselimoğlu Batman and Demirel (2015). In this study, the practicability of paragliding activity on the Altındere Valley Meryemana Stream route was investigated. However, GIS was not used in this application. First, flight points were determined with observational and experimental information, then, whether these points met the technical requirements was checked. However, this method provides the control of the availability of observationally determined paragliding fields in a known region rather than suggesting alternative paragliding fields in a region that is not known. The fact that GIS was not used in the study restricted the project objective and weakened it in terms of the technical infrastructure by suggesting a limited number of flying fields in a restricted area. Furthermore, the fact that only the target area was studied also restricted the widespread effect of the application.
Turkey is a very rich country in terms of geographical and climatic conditions allowing many nature sports to be done with its natural resources and historical texture (Kaplan and Ardahan, 2012). However, this geographical potential, which is still not used sufficiently, needs to be uncovered. Based on this need, in the present study, it was aimed to determine the alternative flying fields suitable for paragliding, which is one of nature sports in Sivas province.

In the determination of the fields for paragliding which is a risky sports branch, attention should be paid to criteria such as the take-off direction, slope and altitude of the hill to paraglide, determination of the required field widths to be able to continue flying for a long time and the fact that landing areas allow for secure landing. With this study, a model has been created for a short-term, low-cost and scientific determination of potential flying fields in accordance with the criteria specified in a wide area such as the provincial border. In accordance with the results obtained, an attempt to contribute to tourism in the region was made by recommending new flying fields to paragliding lovers. Furthermore, a new method has been developed to be able to automatically determine alternative paragliding fields in any city with the help of the introduced GISbased system and user interface program.

\section{THE STUDY AREA}

Sivas provincial border (Turkey) was selected as the study area (Fig. 1). The provincial area, which starts on the high plateaus of Central Anatolia and rises to the east, ends with a mountainous and steep section in the north, east, and south-east. The average altitude is above 1000 meters. The region with a rugged structure is also open to northern winds. The winds blowing in Sivas region consist of the northwest wind blowing from the northwest by $19.3 \%$, the north-east wind blowing from the north-east by $16.8 \%$, the north wind blowing from the north by $18.1 \%$, and the remaining part consists of various winds (Governorship of Sivas, 2017). 

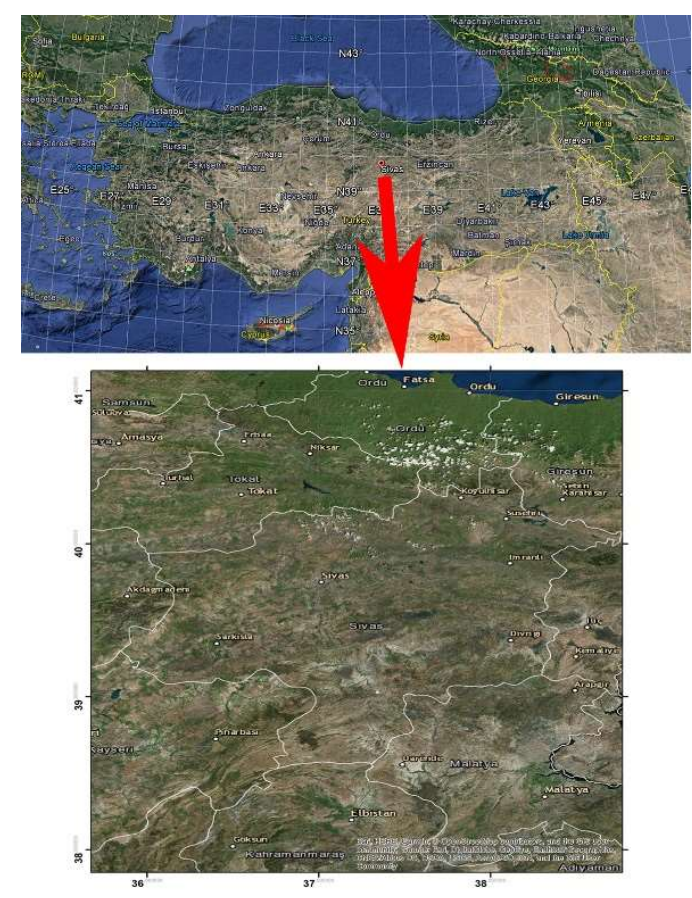

Figure 1. Study Area

When the tourism structure of Sivas province is examined, it is observed that thermal tourism along with cultural tourism mainly comes to the forefront. Mountaineering and trekking attract attention when the nature sports done in the region, which is not known sufficiently in terms of nature sports, are examined (Governorship of Sivas, 2011). However, the city has enough wind potential for paragliding, and it is necessary to determine suitable flying fields in the city to evaluate this feature.

\section{MATERIALS AND METHODS}

This study was carried out in 3 stages. They are given in Fig. 2.

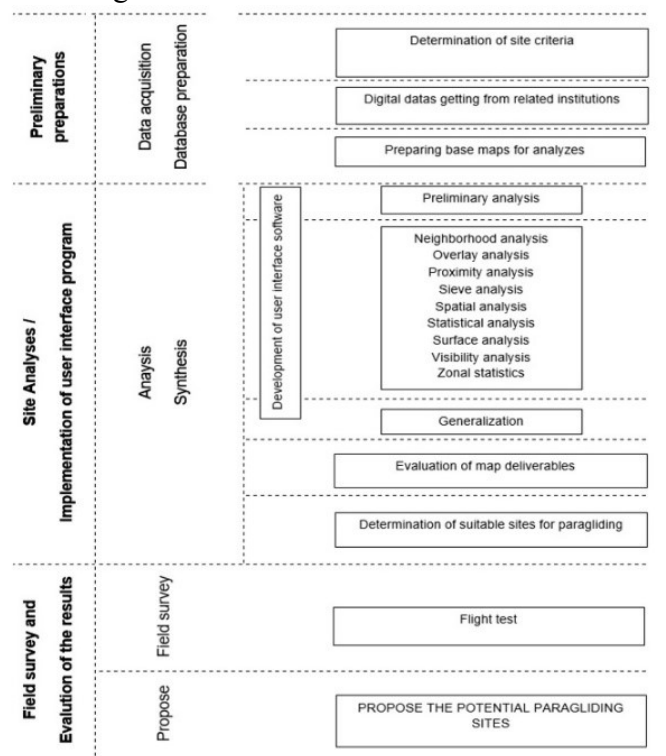

The data presented below were used within the scope of this study.

- Energy transmission lines,

- Stand,

- Highways,

- Streams,

- Lakes/ponds,

- Dams,

- Corine land use,

- Protected areas,

- Military areas,

- Airports,

- Digital Elevation Model (DEM),

- Aspect and

- Wind direction.

Different geographical analyses (Statistical analysis, spatial analysis, zonal statistics analysis, surface analysis, proximity analysis, neighborhood analysis, sieve analysis, overlay analysis, visibility analysis) were used to determine the suitable paragliding areas. These analyses, which is included in decision making and planning techniques, is based on the elimination of unfavorable locations within certain criteria starting from the most unfavorable criteria in determining location suitable for the purpose of the study.

Firstly, the grid network to be used as the basis of the study was formed in a way to cover all Sivas provincial border. The grid size was determined to be $250 \mathrm{~m} \times 250 \mathrm{~m}$ to ensure the sufficient sensitivity in the analyses to be performed. The analysis criteria to be used in the determination of the fields were determined based on the "Flying Altitudes, Conditions and Hill Features" specified in the Turkish Aeronautical Association Flight Training Directive, supported by the International Aviation Federation (Fig. 3). Furthermore, the criteria applied with experiential knowledge for safe flight were extended with the help of experienced pilots (flight instructors with EP license). The analysis criteria created in this context are presented in Fig. 3. The analyses were performed separately for take-off and landing fields.

In this study, although the criteria given in Fig. 3 were used, the relative criteria that may vary according to the flight pilot's professionalism were presented as the parameters that the user could enter in the developed user interface program depending on his/her preference. Furthermore, the user interface program was developed with the Model Builder in ArcGIS 10.1 GIS software environment (Fig. 5) so that it could be used anywhere in the world, on condition that the data listed above were provided. The variable parameters considering in this user interface program were given in Fig. 4.

Figure 2. Stages applied in the study 


\begin{tabular}{|c|c|c|c|}
\hline Factor & Analysis Type & Analysis Site & Suitability criteria \\
\hline \multirow{2}{*}{ Slope } & \multirow{2}{*}{ Slope } & Departure & $18^{\circ}-30^{\circ}$ \\
\hline & & Landing & $0^{\circ}-5^{\circ}$ \\
\hline \multirow{3}{*}{$\Delta H=$ departure-landing } & \multirow{3}{*}{ Surface } & \multirow{6}{*}{ Departure } & $60 \mathrm{~m}<-\leq 350 \mathrm{~m}$ (amateur) \\
\hline & & & $60 \mathrm{~m}<-\leq 600 \mathrm{~m}$ (moderate) \\
\hline & & & $200 \mathrm{~m}<-\leq 1400 \mathrm{~m}$ (professional) \\
\hline \multirow{3}{*}{ Viewshed } & \multirow{3}{*}{ Viewshed } & & Horizontal view $225^{\circ}$ \\
\hline & & & $\begin{array}{l}\text { Horizon Upper / Lower } \\
+90^{\circ} /-90^{\circ}\end{array}$ \\
\hline & & & Visibility distance $2000 \mathrm{~m}$ \\
\hline View $x$ Wind & & & Headwind or wind from sideways (4: \\
\hline \multirow[t]{2}{*}{ Flight Distance } & & & $2 \mathrm{~km}-8 \mathrm{~km}$ \\
\hline & Distance & & \\
\hline Stand & & & $\geq 200 \mathrm{~m}$ \\
\hline Lake & & & $\geq 300 \mathrm{~m}$ \\
\hline Dam-Pond & & & $\geq 500 \mathrm{~m}$ \\
\hline Stream & & & $\geq 300 \mathrm{~m}$ \\
\hline Power line & & & $\geq 500 \mathrm{~m}$ \\
\hline Road & & & $\leq 200 \mathrm{~m}$ \\
\hline Airport & & & $\geq 6 \mathrm{~km}$ \\
\hline Protected Sites & & & $>0 \mathrm{~m}$ \\
\hline Marsh & & & $>0 \mathrm{~m}$ \\
\hline Naked rocky & & & $>0 \mathrm{~m}$ \\
\hline Thana & & & $>0 \mathrm{~m}$ \\
\hline
\end{tabular}

Figure 3.The criteria applied with experiential knowledge for safe flight

\begin{tabular}{lll}
\hline \multicolumn{3}{c}{ Variable criteria } \\
\hline Grid sizes & Distance from stand & Distance from Mor. \\
Province & Distance from lake & Distance from road \\
Slope & Distance from dam / pond & Wind direction \\
$\Delta H$ & Distance from power transmission line \\
Flight distance & Distance from stream \\
\hline
\end{tabular}

Figure 4. Variable criteria

At the end of these processes, grid areas of $250 \mathrm{~m} \mathrm{x}$ $250 \mathrm{~m}$ in size suitable for the flight were determined within the provincial borders of Sivas. Then, the generalization process was performed to eliminate the unfavorable targets determined as individual cells in the entire study area. According to the result obtained, the regions having more targets than a certain field width within the boundary to be decided $(1 \mathrm{~km} \mathrm{x} 1 \mathrm{~km})$ were accepted as the regions suitable for flying.

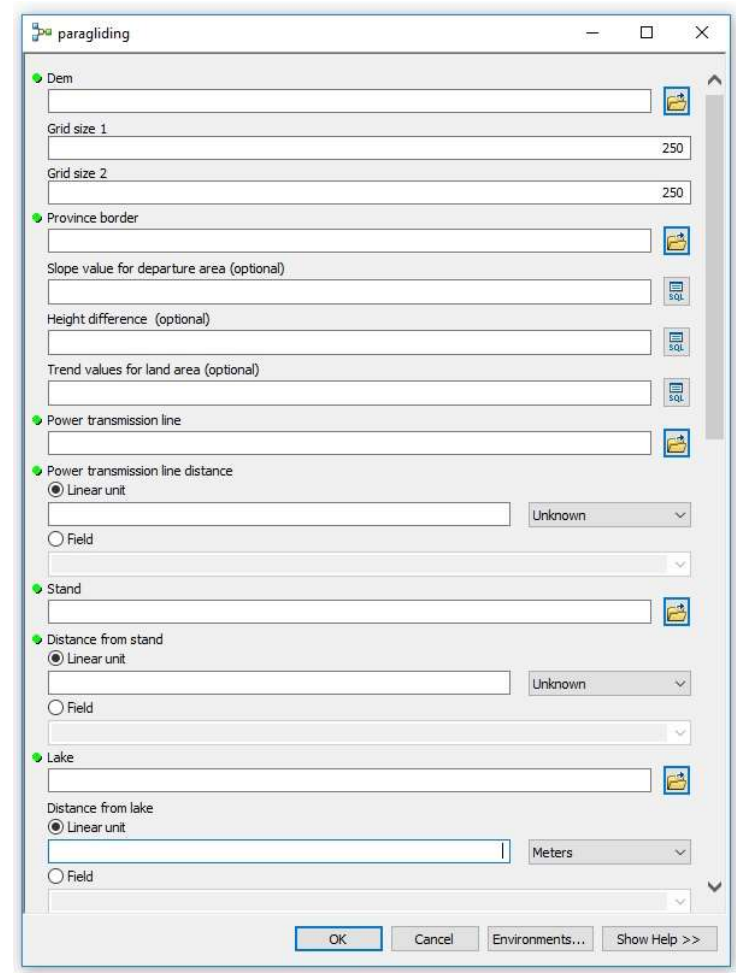

Figure 5. The user interface program developed on ArcGIS software

\section{RESULTS AND DISCUSSION}

It was proceeded to the final stage of the study after determining automatically the fields suitable for flying in the GIS environment by the user interface program developed. 32 fields were determined as the fields suitable for paragliding (Fig. 6). 8 out of the designated target points were randomly visited (Fig. 6), and the suitability of the region for paragliding was validated. The test flight was performed in the field by the professional paragliding pilot with EP license (Fig. 7), and the acceptability of the field as a paragliding field was decided. According to the results obtained; all fields were determined as flight areas from the point of topography but one of them was not accepted due to the missing data of power transmission lines in the area.

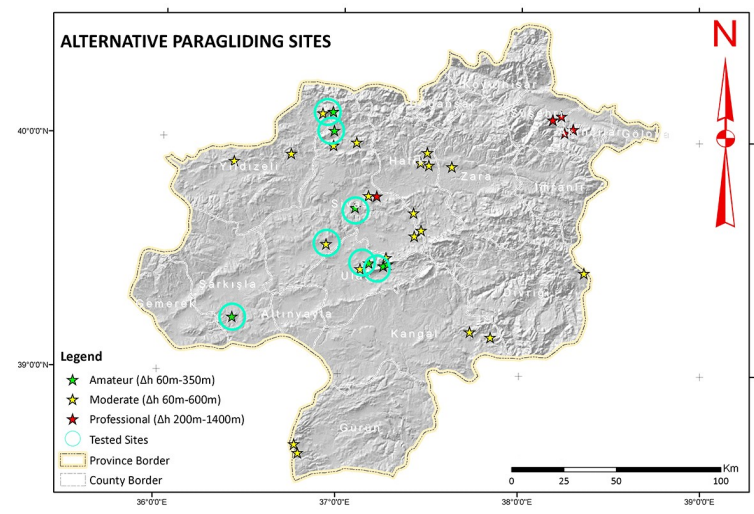

Figure 6. Suitable paragliding fields map 


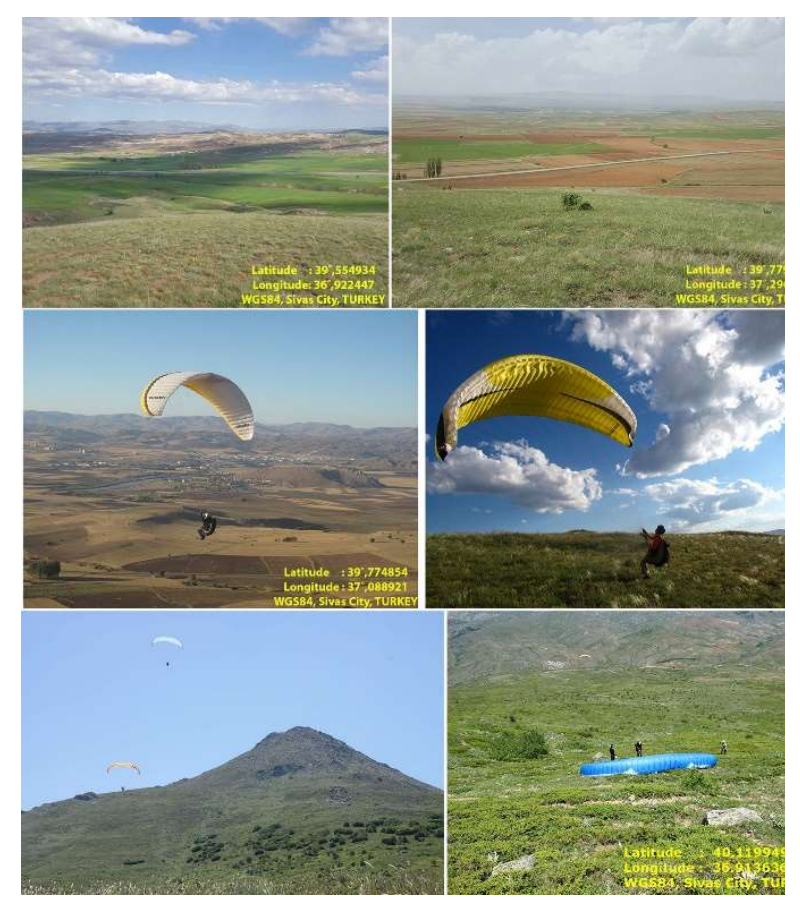

Figure 7. Test flight in some of paragliding fields determined

\section{CONCLUSION}

GIS is an extremely important tool in geographical analysis and provides a great deal of convenience to its users. It is seen that the large areas which cannot be analyzed via observations, can be analyzed objectively and scientifically by the help of GIS. However, the accurate and up-to-dateness of data is of great importance in such GIS studies.

The outcomes of the study have indicated potential new tourism areas by bringing many fields that have not yet been discovered by paragliders to the agenda. It is thought that these fields that can be transformed into attraction centers with various promotional and demonstration flights over time will make positive contributions to the socio-economic development of the region. On the other hand, the outcomes of the study suggest new alternative flying fields that can be reached more easily and quickly by paragliding lovers. This will provide economic benefits by reducing the time and cost that athletes spend to do paragliding and also allow the sports branch to reach larger masses.

Publishing the potential paragliding fields on webbased GIS is extremely important in terms of reaching more users. As a result of publishing this study on the web, it will be more beneficial for paragliding lovers in the future. Thus, paragliding which is one of naturebased sports will stand out further. Consequently, it will be easier to advertise not only paragliding but also other nature-based sports by GIS for people.

\section{ACKNOWLEDGEMENTS}

We would like to express our thanks to Dr. Hakan ULUDAĞ, paragliding pilot with the license of Experienced Pilot (EP), who supported the study with his knowledge and flight tests. In addition, the authors would like to thank Cumhuriyet University for supporting this study under CUBAP M 710 project.

\section{REFERENCES}

Ardahan, F., Yerlisu Lapa, T. 2011. Açık Alan Rekreasyonu: Bisiklet Kullanıcıları ve Yürüyüşçülerin Doğa Sporu Yapma Nedenleri ve Elde Ettikleri Faydalar, Uluslararası İnsan Bilimleri Dergisi, 8(1), 1327-1341

Bahaire, T., Elliott-White, M. 1999. The Application of Geographical Information Systems (GIS) in Sustainable Tourism Planning: A Review, Journal of Sustainable Tourism, 7(2), 159-174

Bell, S., Tyrväinen, L., Sievänen, T., Pröbstl, U., Simpson, M. 2007. Outdoor Recration and Nature Tourism A European Perspective. Living Reviews in Landscape Research, 1(2007), 2

Bishop, I. D., Hulse, D. W. 1994. Prediction of Scenic Beauty Using Mapped Data and Geographic Information Systems, Landscape and Urban Planning, 30(1-2), 5970 .

Boers, B., Cottrell, S. 2007. Sustainable Tourism Infrastructure Planning: A GIS-supported Approach, Tourism Geographies, 9(1), 1-21.

Boyd, S.W., Butler, R.W., Haider, W. 1995. Identifying Criteria and Establishing Parameters for Forest-Based Ecotourism in Northern Ontario Canada. Noda Note No: 7.

Bunruamkaew, K., Murayama, Y. 2012. Land Use and Natural Resources Planning for Sustainable Ecotourism Using GIS in Surat Thani, Thailand, Sustainability, 4(3), 412-429.

Bunruamkaew, K., Murayama, Y. 2011. Site Suitability Evaluation for Ecotourism Using GIS \& AHP: A Case Study of Surat Thani Province, Thailand, Procedia Social and Behavioral Sciences, 21, 269-278

Cerreta, M., Inglese, P., Manzi, M.L. 2016. A MultiMethodological Decision-Making Process for Cultural Landscapes Evaluation: The Green Lucania Project, Procedia - Social and Behavioral Sciences, 216, 578-590

Ceyhan, İ., Çakın, A., Temiz, C., Yavuz, V., Koçak, K., Kahya, C. 2014. Analysis of the Wind Persistence in Southwest Anatolia in terms of Paragliding.

Chen, R. J. 2007. Geographic Information Systems (GIS) Applications in Retail Tourism and Teaching Curriculum, Journal of Retailing and Consumer Services, 14(4), 289-295.

Chhetri, P., Arrowsmith, C. 2008. GIS-Based Modelling of Recreational Potential of Nature-based Tourist Destinations, Tourism Geographies, 10(2), 233-257

Ekinci, E., Yenel, F., Sarol, H. 2012. Doğa Yürüyüşlerine Katılım Motivasyon Ölçeği: Geçerlik ve Güvenirlik Çalışması. Anatolia Turizm Akademisi. 
Falavarjani, N.G. 2015. Wind to Select the Recreation Flying Site, International Journal of Geography and Geology, 4(3), 57-67

Fasching, G., Schippinger, G., Pretscher, R. 1997. Paragliding Accidents in Remote Areas, Wilderness \& Environmental Medicine, 8(3), 129-133.

Fung, T., Wong, F.K.K. 2007. Ecotourism Planning Using Multiple Criteria Evaluation with GIS, Geocarto International, 22(2), 87-105

Hai-ling, G., Liang-qiang, W., Yong-peng, L. 2011. A GIS-Based Approach for Information Management in Ecotourism Region, Procedia Engineering, 15, 19881992

Kaplan, A., Ardahan, F. 2012. Doğa Sporları Yapan Bireylerin Profilleri, Doğa Sporu Yapma Nedenleri ve Elde Ettikleri Faydalar: Antalya Örneği, Karadeniz Sosyal Bilimler Dergisi, 5(8), 93-114

Kienast, F., Degenhardt, B., Weilenmann, B., Wäger, Y., Buchecker, M. 2012. GIS-Assisted Mapping of Landscape Suitability for Nearby Recreation, Landscape and Urban Planning, 105, 385- 399

Kiper, T. 2011. The Determination of Nature Walk Routes Regarding Nature Tourism in North-western Turkey: Şarköy District, Journal of Food Agriculture \& Environment, 9, 622-632

Kliskey, A. D. 2000. Recreation Terrain Suitability Mapping: A Spatially Explicit Methodology for Determining Recreation Potential for Resource Use Assessment, Landscape and Urban Planning, 52(1), 3343.

Kliskey, A.D., Lofroth, E.C., Thompson, W.A., Brown, S., Schreier, H. 1999. Simulating and Evaluating Alternative Resource-use Strategies Using GIS-Based Habitat Suitability Indices, Landscape and Urban Planning, 45, 163-175

Koçak, F., Balcı, V. 2010. Doğada Yapılan Sportif Etkinliklerde Çevresel Sürdürülebilirlik, Ankara Üniversitesi Çevre Bilimleri Dergisi, 2(2), 213-222

Krüger-Franke, M., Siebert, C. H., Pförringer, W. 1991. Paragliding Injuries, British Journal of Sports Medicine, 25(2), 98-101.

Miler, W., Collins, M.G., Frederick, R.S., Cook, E. 1998. An Approach for Greenway Suitability Analysis, Landscape and Urban Planning, 42, 91-105

Özer, E. Z., Çavuşoğlu, F. 2014. The Effect of Local Events to Rural Tourism as a Recreational Activity. International Journal of Science Culture and Sport (IntJSCS), 2(6), 191-202.

Parladır, M.Ö. 2013. Isparta İli'nde Yapılacak Alternatif Turizm Türlerinin ve Yerlerinin GIS Araçları ile
Belirlenmesi. Yüksek Lisans Tezi. Isparta: Süleyman Demirel Üniversitesi Fen Bilimleri Enstitüsü

Pirselimoğlu Batman, Z., Demirel, Ö. 2015. Altındere Vadisi Meryemana Deresi Güzergâhında Doğa Temelli Turizm Etkinliği: Yamaç Paraşütü, İnönü Üniversitesi Sanat Ve Tasarım Dergisi, 5(11), 13-26

Rutherford, J., Kobryn, H. \& Newsome D. 2015. A case study in the evaluation of geotourism potential through geographic information systems: application in a geology-rich island tourism hotspot, Current Issues in Tourism, 18:3, 267-285.

Schulze, W., Richter, J., Schulze, B., Esenwein, S. A., Büttner-Janz, K. 2002. Injury Prophylaxis in Paragliding, British Journal of Sports Medicine, 36(5), 365-369.

Sezgin, M., Gumus, M. 2016. The Evaluation of Beysehir Lake National Park (Konya-Turkey) in the Framework Ecotourism, Journal of Advanced Management Science, 4(4), 342-346

Sivas Valiliği. Sivas 2011 Çevre Durum Raporu. http://www.csb.gov.tr/turkce/dosya/ced/icdr2011/sivas_i cdr2011.pdf Son Erişim Tarihi [23 Aralık 2016]

Sivas Valiliği, http://www.sivas.gov.tr/ilimiz-hakkindagenel-bilgiler

Şentürk, E, Erener, A . Determination Of Temporary Shelter Areas In Natural Disasters By Gis A Case Study For Gölcük/Turkey. International Journal of Engineering and Geosciences 2 (2017): 84-90

Topay, M. 2003. Bartın-Uluyayla Peyzaj Özelliklerinin Rekreasyon-Turizm Kullanımları Açısından Değerlendirilmesi Üzerinde Bir Araştırma. Doktora Tezi. Ankara: Ankara Üniversitesi Fen Bilimleri Enstitüsü Peyzaj Mimarlığı Anabilim Dalı.

Tseng, T. A., Ding, T. J., Collins, J. R., Su, W. Y. 2013. Site Selection Model of Potential Ecotourism Development Area: from the Resources Aspect, In AT Tseng (Chair), ISSRM 2013 Conference, Estes Park Center Co.

Zhang, Y.J., Li, A.J., Fung, T. 2012. Using GIS and Multi-criteria Decision Analysis for Conflict Resolution in Land Use Planning, Procedia Environmental Sciences, $13,2264-2273$

Copyright (C) International Journal of Engineering and Geosciences (IJEG). All rights reserved, including the making of copies unless permission is obtained from the copyright proprietors. 